\title{
Risk Perception in a Developing Country: The Case of Jordan
}

\author{
Mahmaod Al-Rawad ${ }^{1} \&$ Adel Al Khattab ${ }^{1}$ \\ ${ }^{1}$ Department of Accounting and Finance, Al Hussein Bin Talal University, Ma'an, Jordan \\ Correspondence: Mahmaod Al-Rawad, College of Business Administration and Economics, Al-Hussein bin Talal \\ University, Ma'an 71110, Jordan. Tel: 962-790-206-960. E-mail: m_rawd@ yahoo.com
}

Received: November 7, 2014

Accepted: November 24, 2014

Online Published: December 25, 2014

doi:10.5539/ibr.v8n1p81

URL: http://dx.doi.org/10.5539/ibr.v8n1p81

\begin{abstract}
Purpose: Recognizing the importance of risk perception and the poor understanding of the phenomenon in developing countries, this study characterizes risk perception in Jordan.

Design: A mixed quantitative and qualitative survey approach was adopted. Semi-structured interviews were used to identify risks relevant to Jordanian society, then perceptions of these were examined using a questionnaire. Sampling was stratified by province and convenience sampling was adopted within each stratum. The response rate of 53.6 percent was adequate for accurate and useful results representative of the target population. The questionnaire data were analyzed using parametric statistics including principal component analysis and mean analysis.
\end{abstract}

Findings: A cognitive map shows that Jordanians perceived warfare and terrorist attack as the most dreaded, catastrophic and uncontrollable risks to society. Refugee influx was also perceived as a high risk on the dreaded dimension. Although Jordan generates no nuclear electricity, nuclear power was also loaded high on the dreaded factor, confirming that risk perception can be affected by negative international events.

Research Limitations/Implications: A proper interpretation of the cognitive map requires an appreciation of the plasticity of risk, as perceptions are changed by scientific knowledge, media coverage and globalization of risk issues. Future research should examine these changes and determine other possible variables influencing risk ratings at different times. While stratified sampling helped the representativeness of the sample, convenience sampling was applied within each stratum. Future research might use probability sampling instead. This study gives risk analysts and policymakers a basis for understanding and anticipating public responses to risks and improving the communication of risk information among laypeople and decision-makers.

Originality: This study is one of few to develop a cognitive map and investigate factors influencing risk perception in Jordan, in the volatile Middle East. Rather than surveying mainly students, it used a representative sample from Jordan's 12 provinces.

Keywords: cognitive map, Jordan, psychometric approach, risk perception

\section{Introduction}

Risk has been studied intensively from different perspectives, including risk assessment and risk management. Researchers in the risk assessment field investigate the identification and quantification of risk, often in the context of human health and the environment, while risk management is more concerned with communication, decision-making and risk perception (Slovic, 2002). Risk perception has received particular attention for its influence on the attitudes and decisions of individuals and social groups regarding the acceptance of various modern technologies and activities, such as nuclear energy and gene technology.

The concept of risk perception appeared during the 1960s' debate over nuclear power generation. Laypeople's opposition to nuclear technology, according to Sjöberg, Moen, \& Rundmo (2004), raised questions as to the causes of risk perception and why people perceive risk differently. Several models and theories have since been developed, in an attempt to answer these questions. These include the revealed preference model, the psychometric paradigm and cultural theory. The psychometric paradigm, with its superior explanatory power, has dominated the risk perception literature and is regarded as the most influential model in the risk analysis field (Siegrist, Keller, \& Kiers, 2005; Sjöberg, 1996; 1997). Accordingly, the current research adopts the psychometric approach to study risk perception among individuals in Jordan, which will enable a comparison of 
results between Jordan and other countries.

There are two main reasons why such research is vitally important. The first relates to the communication of risks, which aims to provide ordinary individuals with the information they need to make informed decisions about risks to their health, safety and environment. Understanding the way people perceive and evaluate risks will increase the efficiency of risk communication (Morgan, 2002). Secondly, it is essential to know what concerns people and why, so that these views can be incorporated into important political decisions, while an appreciation of the fears and concerns of people from other nations can be used to help improve international relations (Thomson, Önkal-Atay, \& Güvenç, 2003; Sjöberg, 1999).

Despite the vast and expanding research effort in this area, many nations and cultures, including those of the Middle East, have received very little research attention. Jordan presents a challenging area for analysis, given its particular geographical setting in a zone of tension, surrounded by Iraq, Palestine, Syria and Saudi Arabia. This location directly affects Jordan economically, politically and socially. This study therefore addresses an important gap by characterising risk perception in Jordan. It aims a) to identify those technologies and activities that are most relevant to Jordanian society; b) to examine correlations between risk characteristics and demographical variables; c) to examine the correlation of risk perception with demographical variables and risk constructs; and d) to develop a cognitive map of risk perception in Jordan.

\section{Literature Review}

The debate regarding the use of nuclear fusion in generating electricity, which started in Western countries during the 1960s and reached its peak in the 1980s, was characterised by two strongly contrasting views, as reported by Sjöberg et al. (2004). Supporters of the technology perceived it to be safe, based on the risk assessments of scientists and experts, whereas many laypeople perceived it to represent a high risk to human health and the environment. This fundamental divergence of views stimulated interest in the concept of risk perception. Accordingly, many researchers have attempted to understand how participants perceive risks and have investigated disagreements between laypeople and experts regarding various existing and emerging technologies and activities.

\subsection{Risk Perception}

Sowby (1965) was one of the first to investigate and explain such disagreements between laypeople and experts, comparing the levels of risk associated with different technologies and activities in order to provide a base from which individuals would form their perceptions of risk regarding these activities. Starr (1969) went further in his model of revealed preferences, comparing levels of both risks and benefits associated with selected activities and technologies. This model proposed that individuals weigh risks against benefits: if the benefits of a specific technology exceed the risks, people are likely to tolerate those risks; otherwise, it will be regarded as too risky to be used. Otway and Cohen (1975) and Fischhoff, Slovic, Lichtenstein, Read, and Combs (1978) criticise Starr (1969) for basing his analysis on historical data of the risks and benefits of various activities, which may not have reflected current preferences. Slovic, Finucane, Peters, and MacGregor (2004) add that the market price may not reflect the real costs or risks of an activity; the price of cigarettes does not take into account smokers' higher probability of heart disease or cancer.

In an attempt to validate Starr's (1969) findings, Fischhoff et al. (1978) used expressed preference rather than revealed preferences. Their study paved the way for the development of a new approach to risk perception called the psychometric paradigm. Renn and Rohrmann (2000) report that this was based on four main assumptions that enable the risk perception of individuals to be measured and tested: that risk is a subjective concept affected by other factors, rather than an objective entity; that risk criteria should comprise various aspects including 'technical/ physical, and social/psychological ones'; that the model represents the perceptions of laypeople rather than experts and that through using statistical techniques (e.g. factor analysis, multiple regressions), the model can produce a cognitive map of risk perception for different technologies and activities.

Dohle, Keller, and Siegrist (2010) state that the psychometric paradigm not only examines risks and benefits, but also proposes several characteristics or attributes that can be used to measure people's risk perception, including voluntariness, immediacy, knowledge, controllability, newness, chronic vs. catastrophic and common vs. Dreaded. These characteristics, shown in Table 1, which according to Slovic (2000) have been hypothesised to influence laypeople's risk perceptions and acceptance, would later be grouped into a limited number of factors using statistical techniques such as principal component analysis (PCA) or common factor analysis. 
Table 1. Risk perception attributes

\begin{tabular}{llll}
\hline Attribute & Description of Scale & Low (1) & High (7) \\
\hline Knowledge to exposed & $\begin{array}{l}\text { In what degree is the risk associated to each activity, substance, or } \\
\text { technology known to you? }\end{array}$ & Known & Unknown \\
Knowledge to science & $\begin{array}{l}\text { In what magnitude this activity, substance, or technology has the } \\
\text { potential to cause death and catastrophic destruction? }\end{array}$ & Known & Unknown \\
Newness of risk & $\begin{array}{l}\text { Is the risk associated to each activity, substance, or technology new } \\
\text { and non-familiar, or is it old and familiar? }\end{array}$ & New & Old \\
Common- dread & $\begin{array}{l}\text { Is the risk associated to each activity, substance, or technology a } \\
\text { common risk or a terrible risk? }\end{array}$ & Common & Dreaded \\
Control over risk & $\begin{array}{l}\text { In what degree can the risk associated to each activity, substance, or } \\
\text { technology be avoided by the exposed population? }\end{array}$ & Uncontrollable & Controllable \\
Immediacy of effect & $\begin{array}{l}\text { Are the effects of the risk associated to each activity, substance, or } \\
\text { technology immediate, or they take place later in time? }\end{array}$ & Immediate & Delayed \\
Chronic- catastrophic & $\begin{array}{l}\text { Is the risk associated to each activity, substance, or technology new } \\
\text { and non-familiar, or is it chronic or catastrophic? }\end{array}$ & Chronic & Catastrophic \\
Voluntariness of risk & $\begin{array}{l}\text { In what degree is the risk associated to each activity, substance, or } \\
\text { technology faced voluntarily by the exposed population? }\end{array}$ & Voluntary \\
Severity of consequences & $\begin{array}{l}\text { When the risk associated to this activity, substance, or technology } \\
\text { appears: how likely is it that the consequences are fatal? }\end{array}$ & Not sever & Involuntary
\end{tabular}

Source: Bronfman and Cifuentes (2003).

Slovic (1987) reports that these factors were given interpretive names such as 'unknown risk' and 'dreaded risk'. Unknown risk loads highly on scales of perceived newness, perceived scientific knowledge and delay of effect, while dreaded risk loads on such scales as perceived lack of control, dread potential and fatal consequences. These factors are then used to plot the various activities and technologies on a cognitive map, showing their levels of riskiness, which is then used to determine and compare public perceptions associated with those technologies and activities.

The study of risk perception takes a cognitive stance, seeing perception as a mainly cognitive process; this is the foundation of the psychometric paradigm, according to which risk can be understood as a function of general properties of the risk object (Sjöberg, 1996). There are certain hallmarks of objects that make people rate them as risky or not risky. Nine general properties of activities or technologies have been reported as important for subjective risk judgments (Fischhoff, Slovic, Lichtenstein, Read, \& Combs, 2000; Mun, 2004). The degree to which these factors are related to potentially hazardous activities or technologies determines people's risk judgments. However, the approach has been criticised for not considering the potential involvement of factors other than the mere properties of the risk object. Sjöberg (1999) found the level of perceived risk to be related to the probability of harm or injury, whilst demand for risk reduction was related mostly to the expected severity of the consequences, should harm occur.

A large body of literature has investigated laypeople's risk perception using the psychometric approach (Gabriel \& Nyshadham, 2008). The validity of this approach, according to Dohle et al. (2010), has been tested using different sets of risks, different types of participants and sampling, and different countries and cultures. For instance, Fischhoff et al. (1978) studied risk perception for thirty different activities and technologies (e.g. bicycles, food colouring, hunting, skiing, smoking and nuclear power), while Siegrist, Cousin, Kastenholz, \& Wiek (2007) concentrated on one specific technology: nanotechnology. Other studies have focused, for example, on the risks related to food (Sparks \& Shepherd, 1994), to automobile structural defects (Slovic, Mac Gregor, \& Kraus 1987) and to nuclear waste (Sjöberg, 2000).

The model has also been validated in different contexts. Several studies have attempted to replicate or adapt the original study by Slovic, Fischhoff, and Lichtenstein (1980) in other cultures and countries, including Hungary (Englander, Farago, Slovic, \& Fischhoff, 1986), Norway (Teigen, Brun, \& Slovic, 1988), Hong Kong (Keown, 1989), Poland (Goszczynska, Tyszka, \& Slovic, 1991), Japan (Kleinhesselink \& Rosa, 1991), France (Karpowicz-Lazreg \& Mullet, 1993), Italy (Savadori, Rumiati, \& Bonini, 1998), Australia (Rohrmann, 1999), 
China (Lai \& Tao, 2003) and Chile (Bronfman \& Cifuentes, 2003). Others have made cross-cultural comparisons. For example, Sjöberg (2002) used the psychometric paradigm to examine the differences in risk perception regarding nuclear waste among three groups in the same society: nuclear experts, engineers and the public.

\subsection{Risk Characteristics, Perception and Demographic Variables}

The demographical variables used in this study, as recommended by Sjöberg and Wahlberg (2002), are gender, level of education, age and marital status. Understanding differences in risk perception is important in order to understand differences in risky behaviour. This importance is confirmed by Loewenstein, Weber, Hsee, and Welch (2001), who assert that individuals, according to expected utility theory and a consequential list perspective on decision making, are assumed to assess the severity and likelihood of outcomes, perhaps with bias and error, then to integrate this information to arrive at decisions regarding risky behaviour.

This study of risk perception in Jordan, in line with studies reported in the literature, adopts the psychometric approach in an attempt to reflect as closely as possible the real risk perceptions of laypeople in Jordan. It also seeks to make comparisons between Jordan and other countries where possible.

\section{Research Methodology}

Given the research aim and the scarce existing literature on risk perception in Jordan, it would have been difficult to develop specific hypotheses to be tested in this study, which, as recommended by Robson (1993), is instead largely exploratory. It was thus more appropriate to follow the advice of Creswell (1998) to generate data, analyse it and reflect on what theoretical themes the data suggested. To this end, the study utilised both quantitative and qualitative analysis, taking a mixed approach advocated, inter alia, by Saunders et al. (2000).

\subsection{Research Strategy}

The most appropriate approach to obtain primary data was considered to be a survey, whose principal advantage is the ability to collect a certain amount of data from a sizeable population in a highly economical way (Saunders, Lewis, \& Thornhill, 2000).

\subsubsection{Semi-Structured Interviews}

Lemyre, Lee, Mercier, Bouchard, and Krewsk (2006) report that much of the earlier research into laypeople's risk perceptions used general sets of risks, sometimes comprising as many as 90 different activities and technologies, while Dillman (1991) and Eiser, Podpadec, Reicher, and Stevenage (1998) warn that such long lists tend to make research instruments too long for participants to answer comfortably and may affect response rates. The present study needed a high response rate to ensure that the results were representative of the survey population. Furthermore, not all types of activities (e.g. skiing) and technologies cited in the literature would be applicable to Jordanian society. For these reasons, the decision was taken to develop a new list of technologies and activities that would be most relevant to the Jordanian context, using personal face-to-face interviews to gather the required data. The variables identified by means of these exploratory interviews could then be used in the design of a quantitative questionnaire for the second phase of data collection.

Among the three types of personal face-to-face interviews, Healey and Rawlinson (1994) suggest that semi-standardised ones can be used to identify variables. A total of thirty such interviews were undertaken, each lasting around 30 minutes. Purposive sampling was used, since the aim was not to aggregate the data to larger populations but rather to identify the risks perceived as most relevant to Jordanian individuals and society. The interviews were conducted in Arabic, of which the interviewers (researchers) were all native speakers, and responses were recorded by taking notes.

Two broad categories of risk were identified by means of these interviews, namely, personal risks and societal risks, listed in Table 2. The 45 personal risks were those which participants believed to be related to them personally, while 25 of these were also seen as societal risks: technologies and activities that participants believed to have an impact upon Jordanian society as well. This exploratory phase responded to the abovementioned concerns of Eiser et al. (1998) by increasing the relevance of the items and reducing the size of the questionnaire, thus potentially improving the response rate. 
Table 2. List of identified risks (societal and personals risks)

\begin{tabular}{|c|c|c|c|c|c|c|c|c|}
\hline Risk & $\mathrm{P}$ & $\mathrm{S}$ & Risk & $\mathrm{P}$ & $\mathrm{S}$ & Risk & $\mathrm{P}$ & $S$ \\
\hline Alcohol & $\checkmark$ & $\checkmark$ & Global warming & $\checkmark$ & $\checkmark$ & Feeling depressed & $\checkmark$ & - \\
\hline Handguns & $\checkmark$ & $\checkmark$ & Nuclear power & $\checkmark$ & $\checkmark$ & Sandstorms & $\checkmark$ & - \\
\hline Vaccination & $\checkmark$ & $\checkmark$ & Earthquake & $\checkmark$ & $\checkmark$ & Swimming & $\checkmark$ & - \\
\hline Smoking & $\checkmark$ & $\checkmark$ & Flood & $\checkmark$ & $\checkmark$ & Unemployment & $\checkmark$ & - \\
\hline Unemployment & $\checkmark$ & $\checkmark$ & Refugee influx & $\checkmark$ & $\checkmark$ & Bicycles & $\checkmark$ & - \\
\hline Food preservatives & $\checkmark$ & $\checkmark$ & Industrial pollution & $\checkmark$ & $\checkmark$ & Unprotected sex & $\checkmark$ & - \\
\hline Side effect: drugs & $\checkmark$ & $\checkmark$ & Warfare & $\checkmark$ & $\checkmark$ & Falling share prices & $\checkmark$ & - \\
\hline Car accident & $\checkmark$ & $\checkmark$ & Illegal drugs & $\checkmark$ & $\checkmark$ & Overeating & $\checkmark$ & - \\
\hline Inflation & $\checkmark$ & $\checkmark$ & Assault & $\checkmark$ & $\checkmark$ & Robbery & $\checkmark$ & - \\
\hline Gene technology & $\checkmark$ & $\checkmark$ & Terrorist attack & $\checkmark$ & $\checkmark$ & Storms & $\checkmark$ & - \\
\hline National conflicts & $\checkmark$ & $\checkmark$ & Motor vehicles & $\checkmark$ & - & Train travel & $\checkmark$ & - \\
\hline Extreme poverty & $\checkmark$ & $\checkmark$ & Microwave ovens & $\checkmark$ & - & Mobile phones & $\checkmark$ & - \\
\hline Pesticides & $\checkmark$ & $\checkmark$ & Surgery & $\checkmark$ & - & Feeling lonely & $\checkmark$ & - \\
\hline Robbery & $\checkmark$ & $\checkmark$ & Aircraft travel & $\checkmark$ & - & Being bullied & $\checkmark$ & - \\
\hline Fire & $\checkmark$ & $\checkmark$ & Eating red meat & $\checkmark$ & - & Pollution & $\checkmark$ & - \\
\hline
\end{tabular}

P: personal risk, S: society risk.

\subsubsection{Self-Administered Questionnaire}

A self-administered questionnaire was chosen as the main research instrument for the second phase of the empirical study, as such instruments are widely used in risk perception studies and can yield meaningful results (Sjöberg, 2000). More generally, Oppenheim (1992) recommends self-administered questionnaires for their high response rate, accurate sampling and freedom from interviewer bias. Specialised qualitative risk characteristic scales and associated questions were based on psychometric instruments extensively used within the established paradigm (Fischhoff et al., 1978; Slovic, Fischhoff, \& Lichtenstein, 1981; Slovic, 1987; Slovic et al., 1987).

The questionnaire, which was developed in English and translated into Arabic, took the form of a formalised questionnaire of ten A4 pages, structured into three sections. In the first, participants were asked to report personal demographical variables: gender, level of education, age and marital status. In the second section, they were asked to rate different types of risk based on nine risk attributes listed in Table 1, using a seven-point Likert ordinal scale. The third section aims to measure the risks on the social/personal diminutions. Respondents were asked to rate all the risks using ten-point Likert scale where 1 represents no risk and 10 represent high risk (Bronfman \& Cifuentes, 2003). The analysis presented here is limited to the 25 risks listed in Table 2 that were seen as both personal and societal.

Unlike previous risk perception studies (e.g. Slovic et al., 1980; Kleinhesselink \& Rosa, 1991; Keown, 1989; Englander et al., 1986; and Teigen et al., 1988), this study adopted stratified sampling, ensuring representation of each of the 12 Jordanian provinces. Selecting a representative sample that included participants from different geographical locations is in line with earlier studies (e.g. Rohrmann, 1999; Bronfman \& Cifuentes, 2003). Like many of the cross-country comparisons following the psychometric paradigm (e.g. Karpowicz-Lazreg \& Mullet, 1993; Boholm, 1998), a convenience sample was taken from each stratum, comprising people who for whatever reasons were available and willing to participate.

A total of 800 questionnaires were distributed between May and August 2013. Participants were at least 18 years old; ages ranged from 18 to 62 and the mean age was 30.37 ( $\mathrm{SD}=11.58$ ). The questionnaire took on average 22 minutes to complete. Of the 800 questionnaires, 429 were returned and usable, giving a response rate of 53.6 percent, which was adequate to ensure that the survey results were representative of the target population and able to produce accurate and useful results. The output of the chi-squared test indicates that there was no statistically significant difference between respondents and non-respondents with respect to gender $\left(X^{2}=5.212\right.$, $\mathrm{p}=0.072,2$-sided). The sample, despite a relatively high level of educational attainment, is representative of the target population and findings can be generalised to the entire population.

Table 3 shows that $56.7 \%$ of the 429 respondents $(\mathrm{N}=243)$ were male and $43.2 \%(\mathrm{~N}=184)$ female (two missing values). As to educational classification, almost half $(48.7 \%, \mathrm{~N}=208)$ were non-graduates or undergraduate 
students, while $51.2 \%(\mathrm{~N}=220)$ were graduates or postgraduate students (one missing value). By age range, a third $(\mathrm{N}=139)$ were under 20, slightly fewer $(\mathrm{N}=123)$ were aged $21-30,17 \%(\mathrm{~N}=73)$ were $31-40,12.3 \%(\mathrm{~N}=53)$ were $41-50$ and $9.3 \%(\mathrm{~N}=40)$ were over 50 (one missing value). Finally, only about a quarter of participants $(\mathrm{N}=114)$ had children.

Table 3. Descriptive statistics of respondents' characteristics

\begin{tabular}{lcclcc}
\hline Gender & Frequency & $\%$ & Participants with children & Frequency & $\%$ \\
\hline Male & 243 & 56.7 & Yes & 114 & 26.5 \\
Female & 184 & 43.2 & No & 315 & 73.5 \\
Missing value & 2 & 0.01 & Missing value & - & - \\
\hline Age (years) & Frequency & $\%$ & Education & Frequency & $\%$ \\
\hline 20 or under & 139 & 32.4 & Undergraduate & 208 & 48.7 \\
$21-30$ & 123 & 28.6 & Postgraduate & 220 & 51.2 \\
$31-40$ & 73 & 17.0 & Missing value & 1 & - \\
$41-50$ & 53 & 12.3 & & & \\
51 and over & 40 & 9.3 & & & \\
\hline
\end{tabular}

\subsection{Data Analysis}

Descriptive statistics were computed to examine the hazards that preoccupied the participants. PCA was used, as suggested by Burns (2000), to detect a structure in the relationship between variables. The absolute values of the risk attributes' weight should be more than 0.45 to represent a factor (Rust \& Golombok, 1989). In line with Sjöberg (2000) and Siegrist et al. (2005), a PCA was conducted on participants' risk ratings of hazards to determine the underlying structure and commonalities. The results of PCA were then computed for each identified component to be used in building the cognitive map and testing group differences using mean analysis.

\section{Findings and Discussion}

In most studies utilising the psychometric paradigm, averages are taken across all participants, and the data matrix is submitted to a principal component analysis. As a result of such a research approach, individual differences are usually neglected (Siegrist et al., 2005). In this study, demographical variables were used to explain individual differences in risk perception.

\subsection{Risk Characteristics and Demographical Variables}

The mean risk perception ratings by the Jordanian subjects across the nine risk characteristics, as indicated in Table 4, show no significant disparities among the gender, education or marital status categories (all p>0.05).

1

Table 4. Mean and standard deviation (SD) of risk characteristics by gender, education and marital status

\begin{tabular}{llcccccc}
\hline \multirow{2}{*}{ Characteristics } & & \multicolumn{2}{c}{ Gender } & \multicolumn{2}{c}{ Education } & \multicolumn{2}{c}{ Marital status } \\
\cline { 3 - 8 } & & Male & Female & Under & Post & Yes & No \\
\hline \multirow{2}{*}{ Knowledge of exposure } & Mean & 2.77 & 2.79 & 2.86 & 2.70 & 2.88 & 2.65 \\
& SD & 1.022 & 1.253 & 1.073 & 1.178 & 1.243 & 1.003 \\
Knowledge of science & Mean & 2.23 & 2.15 & 2.51 & 2.61 & 2.72 & 2.49 \\
Newness & Mean & 4.50 & 4.55 & 4.19 & 4.76 & 4.41 & 4.65 \\
Common/Dreaded & SD & 1.213 & 1.220 & 1.254 & 1.123 & 1.298 & 1.106 \\
Mean & 4.05 & 3.88 & 4.09 & 3.87 & 4.10 & 3.82 \\
Control & SD & 0.930 & 0.801 & 0.847 & 0.893 & 0.890 & 0.847 \\
& Mean & 3.50 & 3.51 & 3.47 & 3.52 & 3.36 & 3.65 \\
\hline
\end{tabular}




\begin{tabular}{|c|c|c|c|c|c|c|c|}
\hline \multirow{2}{*}{ Immediacy } & Mean & 3.53 & 3.51 & 3.78 & 3.33 & 3.68 & 3.35 \\
\hline & $S D$ & 1.187 & 1.294 & 1.326 & 1.133 & 1.343 & 1.196 \\
\hline \multirow{2}{*}{ Chronic/Catastrophic } & Mean & 4.21 & 4.16 & 4.09 & 4.25 & 4.30 & 4.08 \\
\hline & $S D$ & 0.979 & 0.737 & 0.853 & 0.880 & 0.831 & 0.899 \\
\hline \multirow{2}{*}{ Voluntariness } & Mean & 3.97 & 3.76 & 3.76 & 3.95 & 3.82 & 3.93 \\
\hline & $S D$ & 1.063 & 0.979 & 1.135 & 0.937 & 1.070 & 0.983 \\
\hline \multirow{2}{*}{ Severity of consequences } & Mean & 3.85 & 3.90 & 4.10 & 3.98 & 4.09 & 3.92 \\
\hline & $S D$ & 0.890 & 0.881 & 0.879 & 0.872 & 0.990 & 0.957 \\
\hline
\end{tabular}

$* * \mathrm{p}<0.001, * \mathrm{p}<0.05$

The mean age ratings, on the other hand, indicate that age differences were significant for the knowledge of exposure $(\mathrm{p}=0.047)$ and immediacy $(\mathrm{p}=0.034)$ characteristics (Table 5). The group aged 41 to 50 assessed themselves as being more knowledgeable about alcohol, warfare, terrorist attacks, refugee influx and nuclear power risks. This group also assessed the immediacy of terrorist attack, nuclear power and national conflict as greater than the other groups did. This finding is line with that of Frank et al. (2010), who stated that risk perception is likely to be influenced by a person's age cohort; age can signify norms of social interaction as well as experience associated with specific stages in the life cycle.

Table 5. Mean and standard deviation of risk characteristics by age group

\begin{tabular}{|c|c|c|c|c|c|c|}
\hline \multirow{2}{*}{ Characteristics } & & \multicolumn{5}{|c|}{ Age group } \\
\hline & & Under 20 & $21-30$ & $40-31$ & $41-50$ & 51 and over \\
\hline \multirow{2}{*}{ Knowledge of exposure } & Mean & 2.97 & 2.64 & 2.91 & $3.32 *$ & 2.53 \\
\hline & $S D$ & 1.114 & 1.080 & 1.425 & 1.055 & 1.029 \\
\hline \multirow{2}{*}{ Knowledge of science } & Mean & 2.64 & 2.55 & 2.72 & 2.92 & 2.72 \\
\hline & $S D$ & 1.030 & 1.082 & 1.100 & 1.023 & 0.981 \\
\hline \multirow{2}{*}{ Newness } & Mean & 4.50 & 4.60 & 4.48 & 4.10 & 4.91 \\
\hline & $S D$ & 1.338 & 1.145 & 1.170 & 1.200 & 1.137 \\
\hline \multirow{2}{*}{ Common/Dreaded } & Mean & 4.33 & 4.09 & 3.67 & 3.98 & 3.69 \\
\hline & $S D$ & 0.810 & 0.832 & 1.015 & 0.846 & 0.780 \\
\hline \multirow{2}{*}{ Control } & Mean & 3.46 & 3.45 & 3.56 & 3.55 & 3.47 \\
\hline & $S D$ & 0.655 & 1.039 & 0.746 & 0.899 & 0.633 \\
\hline \multirow{2}{*}{ Immediacy } & Mean & 3.33 & 3.41 & 3.46 & $3.99 *$ & 3.58 \\
\hline & $S D$ & 1.336 & 1.137 & 1.133 & 1.443 & 0.869 \\
\hline \multirow{2}{*}{ Chronic/Catastrophic } & Mean & 4.26 & 4.37 & 4.22 & 4.15 & 3.95 \\
\hline & $S D$ & 0.717 & 1.178 & 1.131 & 0.623 & 0.628 \\
\hline \multirow{2}{*}{ Voluntariness } & Mean & 3.79 & 4.03 & 3.95 & 3.52 & 4.07 \\
\hline & $S D$ & 1.345 & 0.732 & 1.070 & 0.976 & 0.835 \\
\hline \multirow{2}{*}{ Severity of consequences } & Mean & 4.03 & 4.02 & 3.98 & 3.89 & 3.88 \\
\hline & $S D$ & 0.910 & 0.801 & 0.989 & 1.021 & 1.051 \\
\hline
\end{tabular}

** $\mathrm{p}<0.001,{ }^{*} \mathrm{p}<0.05$

\subsection{Risk Perception and Demographical Variables}

The mean risk perception ratings across the twenty-five risks indicate no significant disparities among gender, education or marital status categories (all $\mathrm{p}>0.05$ ). Although males, according to Davidson and Freudenburg 
(1996), Slovic (1999), Rowe and Wright (2001) and Kellens, Zaalberg, Neutens, Vanneuville, and De Maeyer (2011), tend to judge risks as both smaller and less problematic than do females, Siegrist (2000) found that gender was a weak predictor of risks perceived. Savage (1993) and Dosman, Wiktor, and Steve (2001) explain further that females perceive only particular risks to be larger; these include house fires, road accidents, food risks, violence, radioactive waste and global warming. Educational level was found not to be an important influencer of risk perception in Jordan. This result is consistent with that of Sjöberg (2004), but contradicts that of Rowe and Wright (2001), who found lower perceived risks among highly educated individuals. Sundblad, Biel, and Gärling (2007) explain that education could increase a sense of control that implies lower perceived risks. They also suggest that education could be systematically associated with the degree of 'correctness' regarding the probability and consequence of an accident, which could imply either higher or lower risk perception depending on the existence and degree of misperception of risks in the general population. Although marital status can influence the perception of particular risks, such as that of coffee pests for coffee farmers (Frank, Eakin, \& López-Carra, 2010), it is not an important influencer of risk perception in Jordan.

Table 6. Mean of risk perception by gender, education and marital status

\begin{tabular}{|c|c|c|c|c|c|c|}
\hline \multirow{2}{*}{ Risk } & \multicolumn{2}{|c|}{ Gender } & \multicolumn{2}{|c|}{ Education* } & \multicolumn{2}{|c|}{ Marital status } \\
\hline & Male & Female & UG & PG & Married & Single \\
\hline Alcohol & 3.31 & 3.28 & 3.34 & 3.34 & 3.24 & 3.35 \\
\hline Handguns & 3.66 & 3.43 & 3.65 & 3.43 & 3.42 & 3.68 \\
\hline Vaccination & 3.66 & 3.65 & 3.70 & 3.62 & 3.63 & 3.69 \\
\hline Smoking & 3.68 & 3.62 & 3.74 & 3.55 & 3.60 & 3.71 \\
\hline Unemployment & 3.79 & 3.63 & 3.54 & 3.92 & 3.94 & 3.49 \\
\hline Food preservatives & 3.84 & 3.84 & 3.90 & 3.75 & 3.80 & 3.88 \\
\hline Side effect: drugs & 3.73 & 3.75 & 3.75 & 3.71 & 3.78 & 3.69 \\
\hline Car accident & 3.70 & 3.71 & 3.67 & 3.74 & 3.69 & 3.71 \\
\hline Inflation & 3.87 & 3.88 & 3.85 & 3.90 & 3.88 & 3.86 \\
\hline Gen technology & 4.08 & 3.86 & 3.96 & 4.00 & 4.04 & 3.91 \\
\hline National conflicts & 3.89 & 3.98 & 3.94 & 3.93 & 3.94 & 3.93 \\
\hline Extreme poverty & 3.97 & 3.86 & 3.94 & 3.91 & 3.94 & 3.90 \\
\hline Pesticides & 3.83 & 3.81 & 3.76 & 3.88 & 3.91 & 3.73 \\
\hline Robbery & 3.81 & 3.64 & 3.83 & 3.65 & 3.70 & 3.76 \\
\hline Fire & 3.94 & 4.05 & 4.04 & 3.95 & 3.96 & 4.03 \\
\hline Global warming & 4.04 & 4.04 & 3.99 & 4.00 & 3.99 & 4.01 \\
\hline Nuclear power & 3.96 & 4.01 & 3.91 & 4.08 & 4.06 & 3.91 \\
\hline Earthquake & 4.14 & 3.88 & 4.00 & 4.06 & 4.07 & 3.97 \\
\hline Flood & 4.18 & 3.96 & 4.11 & 4.03 & 4.04 & 4.11 \\
\hline Refugee influx & 3.98 & 4.13 & 3.99 & 4.13 & 4.10 & 4.00 \\
\hline Industrial pollution & 4.06 & 4.03 & 4.03 & 4.06 & 4.08 & 4.01 \\
\hline Warfare & 3.92 & 3.98 & 3.97 & 3.94 & 4.00 & 3.89 \\
\hline Illegal drugs & 3.83 & 3.36 & 3.56 & 3.69 & 3.75 & 3.45 \\
\hline Assault & 3.83 & 3.85 & 3.90 & 3.79 & 3.81 & 3.86 \\
\hline Terrorist attack & 3.91 & 3.91 & 3.91 & 3.93 & 3.95 & 3.87 \\
\hline
\end{tabular}

*UG: undergraduate, $\mathrm{PG}$ postgraduate.

Contrary to the findings of Savage (1993) and Kellens et al. (2011), the mean risk-perception ratings by 
Jordanians across the twenty-five risks, listed in Table 6 and 7, indicate a positive significant correlation between perceived risk of car accidents and age $(\mathrm{p}<0.05)$, whereby participants older than 51 years perceived this risk as higher than other groups did. This finding contradicts the main theme of risk perception, where the older the person, the lower the perceived risk. Weinstein (1987) calls this phenomenon unrealistic optimism: a general optimism about the outcome of an event which exists for both men and women across age categories. In the context of Jordan, there appears to have been the opposite phenomenon of unrealistic pessimism. However, the high rating of road accidents by Jordanian participants over 51 can be explained if three related independent variables are included; these are participants' occupation, driving experience and accident history.

Table 7. Mean of risk perception by age group

\begin{tabular}{|c|c|c|c|c|c|}
\hline \multirow{2}{*}{ Risk } & \multicolumn{5}{|c|}{ Age } \\
\hline & Under 20 & $21-30$ & $40-31$ & $41-50$ & 51 and over \\
\hline Alcohol & 3.22 & 3.46 & 3.51 & 3.19 & 3.15 \\
\hline Handguns & 3.63 & 3.49 & 3.91 & 3.28 & 3.44 \\
\hline Vaccination & 3.58 & 3.84 & 3.58 & 3.61 & 3.70 \\
\hline Smoking & 3.63 & 3.50 & 4.11 & 3.68 & 3.37 \\
\hline Unemployment & 3.92 & 3.70 & 3.74 & 3.46 & 3.73 \\
\hline Food preservatives & 3.93 & 3.88 & 3.84 & 3.86 & 3.68 \\
\hline Side effect: drugs & 3.76 & 3.84 & 3.69 & 3.72 & 3.68 \\
\hline Car accident & 3.69 & 3.58 & 3.59 & 3.60 & $4.06 *$ \\
\hline Inflation & 3.82 & 4.03 & 3.83 & 3.99 & 3.72 \\
\hline Gen technology & 4.34 & 4.00 & 3.90 & 4.13 & 3.47 \\
\hline National conflicts & 4.14 & 3.94 & 3.62 & 4.00 & 3.91 \\
\hline Extreme poverty & 4.26 & 3.89 & 3.70 & 3.88 & 3.80 \\
\hline Pesticides & 4.01 & 3.79 & 3.76 & 3.76 & 3.77 \\
\hline Robbery & 4.03 & 3.85 & 3.61 & 3.81 & 3.32 \\
\hline Fire & 4.21 & 3.81 & 3.83 & 4.04 & 4.03 \\
\hline Global warming & 4.26 & 3.84 & 3.98 & 4.15 & 3.73 \\
\hline Nuclear power & 4.22 & 3.84 & 3.97 & 4.08 & 3.78 \\
\hline Earthquake & 4.38 & 4.10 & 3.97 & 4.03 & 3.57 \\
\hline Flood & 4.37 & 4.05 & 4.04 & 4.15 & 3.73 \\
\hline Refugee influx & 4.22 & 3.94 & 3.81 & 4.30 & 3.94 \\
\hline Industrial pollution & 4.20 & 3.99 & 4.01 & 4.20 & 3.81 \\
\hline Warfare & 4.09 & 3.91 & 3.91 & 4.03 & 3.78 \\
\hline Illegal drugs & 3.93 & 3.79 & 3.75 & 3.19 & 3.34 \\
\hline Assault & 4.16 & 3.75 & 3.59 & 3.78 & 3.82 \\
\hline Terrorist attack & 4.08 & 3.78 & 3.90 & 4.07 & 3.69 \\
\hline
\end{tabular}

\subsection{Risk Perception and Risk Constructs}

The mean risk ratings were computed, based on two constructs: perceived societal risk and perceived personal risk. As Table 8 shows, the highest societal risks were perceived to be refugee influx, terrorist attack, warfare, nuclear power and unemployment, while the equivalent personal risks were refugee influx, nuclear power, car accidents, warfare and pollution. Political risks (refugee influx and warfare) were perceived as high risks both personally and for society. Like Chileans (Bronfman \& Cifuentes, 2003), Jordanians perceived environmental hazards (pollution) and natural disasters (nuclear power) as high societal risks as well as high personal risks. 
Table 8. Perceived societal and personal risks

\begin{tabular}{|c|c|c|c|c|c|c|c|}
\hline No & Risk & Personal $\square$ & Societal $\square$ & No & Risk & Personal & Societal \\
\hline 1. & Alcohol & 12 & 16 & 14. & Robbery & 24 & 24 \\
\hline 2. & Handguns & 16 & 18 & 15 . & Fire & 14 & 12 \\
\hline 3. & Vaccination & 11 & 25 & 16. & Global warming & 22 & 11 \\
\hline 4. & Smoking & 15 & 21 & 17. & Nuclear power & 2 & 4 \\
\hline 5 & Unemployment & 13 & 5 & 18 & Earthquake & 23 & 19 \\
\hline 6. & Food preservatives & 8 & 22 & 19. & Flood & 15 & 23 \\
\hline 7. & Side effect: drugs & 17 & 10 & 20. & Refugee influx & 1 & 1 \\
\hline 8. & Car accident & 3 & 17 & 21. & Industrial pollution & 5 & 10 \\
\hline 9. & Inflation & 18 & 6 & 22. & Warfare & 4 & 3 \\
\hline 10. & Gene technology & 9 & 9 & 23. & Illegal drugs & 7 & 13 \\
\hline 11. & National conflicts & 7 & 7 & 24. & Assault & 21 & 15 \\
\hline 12. & Extreme poverty & 6 & 8 & 25 & Terrorist attack & 19 & 2 \\
\hline 13. & Pesticides & 20 & 14 & & & & \\
\hline
\end{tabular}

$\square$ Rank order of perceived risks: 1 indicates the highest risk.

\subsection{Cognitive Map of Risk Perception in Jordan}

PCA was conducted as an extraction method and varimax with Kaiser normalisation as a rotation method. In line with previous literature (e.g. Slovic, 2000; Bronfman \& Cifuentes, 2003), outliers strongly influenced correlation coefficients. Rank correlations among the nine risk attributes were therefore computed and submitted to a PCA. Based on the scree-test plot, two components can explain the correlations among the attributes and account for 68.35 percent of the variance. The first of the two orthogonal components of the rotated factor loadings, as shown in Table 9, was highly correlated with newness, common/dreaded and chronic. This component is labelled dread of risk. The second component was positively correlated with knowledge of exposure and severity, and negatively correlated with voluntariness of risk. This component is labelled knowledge of risk.

Table 9. Loadings from a principal components analysis across nine risk attributes

\begin{tabular}{lcc}
\hline \multirow{2}{*}{ Risk attributes } & \multicolumn{2}{c}{ Components } \\
\cline { 2 - 3 } & 1 & 2 \\
\hline Knowledge of exposure & 0.346 & $0.872 \square$ \\
Knowledge of science & $0.486 \square$ & 0.358 \\
Newness & $0.932 \square$ & 0.169 \\
Common/Dreaded & $0.913 \square$ & 0.139 \\
Control & -0.257 & $-0.512 \square$ \\
Immediacy & $0.627 \square$ & -0.481 \\
Chronic/Catastrophic & $0.903 \square$ & 0.121 \\
Voluntariness & 0.065 & $-0.835 \square$ \\
Severity of consequences & 0.535 & $0.659 \square$ \\
\hline
\end{tabular}

Rotation converged in 3 iterations.

Figure 1 is a two-dimensional plot of the perceived risks, using factor scores of dread of risk and knowledge of risk as coordinates. The factors in this space reflect the degree to which the risk of a particular hazard is understood and the degree to which the risk evokes a feeling of dread. The further to the right a data point, the more that risk was dreaded, while the closer to the top of the space, the less well the risk was known. Slovic 
(2000) suggests that laypeople's perceptions of risk tend to be closely related to the position of a hazard within the factor space. The higher a hazard's score on this factor, as explained by Cha (1997), the higher the perceived risk, the more people want to see its current risks reduced, and the more they want to see rigorous regulation employed to achieve the desired reduction in risk.

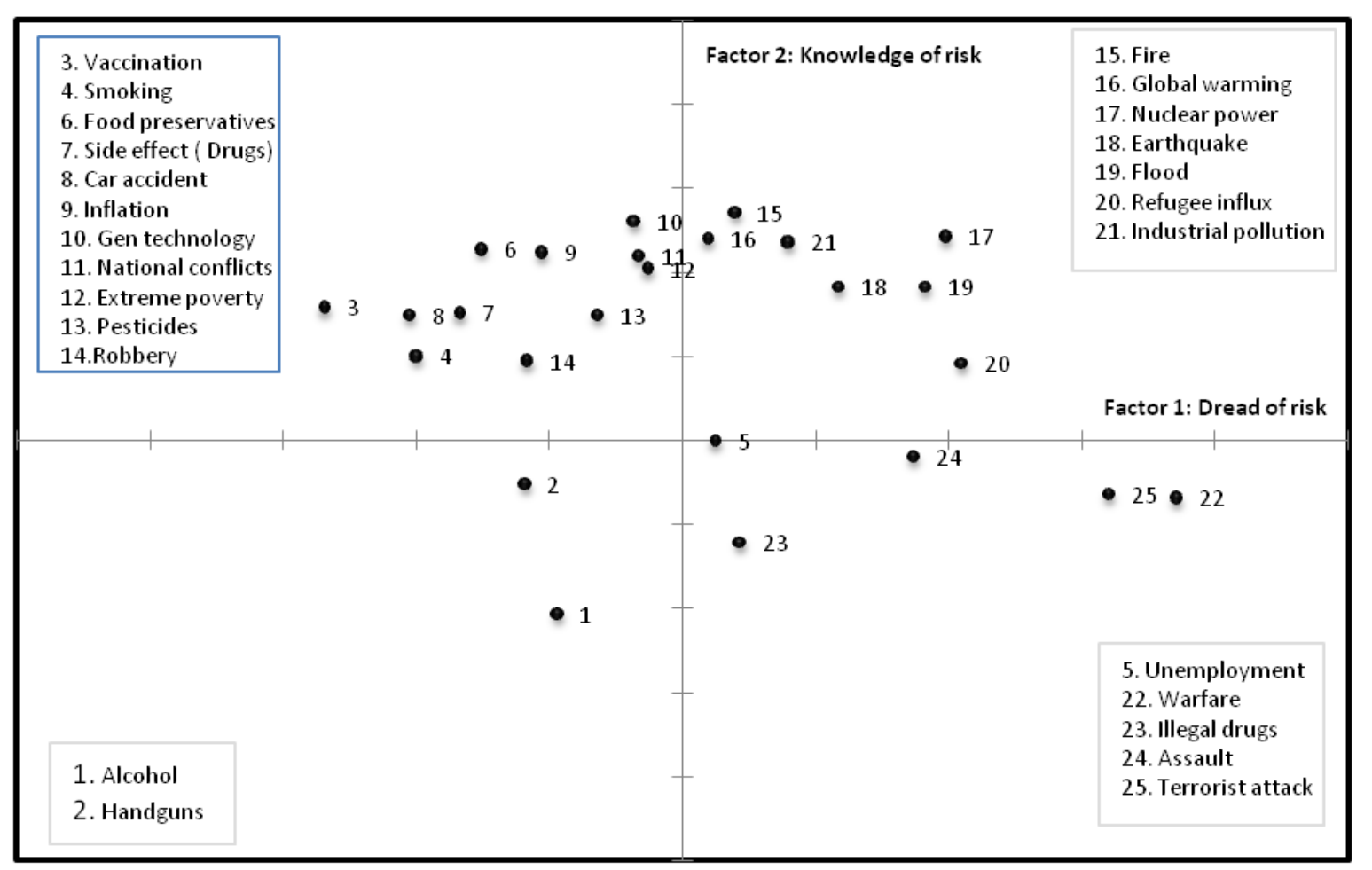

Figure 1. Cognitive map of risk in Jordan

\subsubsection{Dreaded and Known Risks}

The plots in the lower right quadrant of Figure 1 indicate that unemployment, warfare, illegal drugs, assault and terrorist attack had high loadings on both the dread and knowledge factors. Thus, these were perceived as the most dreaded but known risks. The most prominent result to emerge from Figure 1 is the positions and close proximity of the risk items 22 (warfare) and 25 (terrorist attack), on the extreme right of the plot. Like Jordanian respondents in the study of Al Khattab, Anchor, and Davies (2007), the current Jordanian sample viewed the risks from these activities as more dreadful, more catastrophic and more uncontrollable than any of the others. On an international level, however, this finding contrasts dramatically with those reported by other countries, where nuclear power was the most dominant risk (Slovic, Flynn, Mertz, Poumadere, \& Mays 1996; Hinman, Rosa, Kleinhesselink, \& Lowinger, 1993; Fischhoff et al., 1978; Sjöberg, Kolarova, Rucai, \& Bernstrom, 2000; Thomson et al., 2003).

Warfare and terrorist attack were thus perceived as the most dreadful hazards but were also among the best known. This result was to be expected, since Jordan is located in the politically volatile Middle East region, which has witnessed several wars and conflicts over the last two decades, including those in Iraq in 2003, Lebanon and Israel in 2006, Gaza in 2008 and, since 2011, the widespread negative outcomes of the Arab Spring, particularly in Syria. The risk of violence spilling over has put Jordan on high alert. In recent years, furthermore, Jordanian society has suffered from several terrorist events. In 2005 there was a series of coordinated bomb attacks on three hotels in Amman, when more than 60 people were killed and 115 injured (Finer \& Mehdawi, 2005). Such events have affected how people perceive risks related to terrorist attacks. According to Knuth et al. (2013), direct exposure to risk heightens individuals' risk perceptions.

\subsubsection{Dreaded and Unknown Risks}

In the top right quadrant of Figure 1, the risks of fire, global warming, nuclear power, earthquake, flood, refugee influx and industrial pollution were perceived as dreaded and unknown. Participants perceived the risk 
associated with refugee influx to be third highest (after war and terrorism) on the dread dimension and relatively close to the mid-range on the knowledge dimension. This result may be attributed to the country's refugee history, beginning in 1948 as a result of Arab-Israeli conflict. Between 1948 and 1968, Brynen (2006) reports that Jordan hosted around two million registered Palestinian refugees, most of whom continue to live in Jordan. The most recent large-scale wave of Palestinian migration to Jordan, as reported by Chatelard (2010), was that of returnees from Gulf countries, most of them expelled from Kuwait following the 1991 Gulf War. Jordan has also hosted forced migrants from other countries in the Middle East, such as Lebanon during the 1975-1991 civil war, and Iraq since the 1991 Gulf War and after the 2003 removal of Saddam Hussein. Most recently, the conflict in neighbouring Syria has continued to impact Jordan, as an influx of refugees, cross-border fighting and a thwarted Al-Qaeda plot have raised fears of insecurity (Freedom House, 2013). The office of the United Nations High Commissioner for Refugees estimates that there were more than 160000 Syrian refugees in Jordan at the end of 2013, with steady increases in arrivals straining Jordan's resources and social services. This has exerted heavy pressure on infrastructure, public services and housing, destabilising the redistribution of resources and capital.

Another risk loaded high on the dread factor was nuclear power, which also scored relatively highly on the 'unknown' dimension. Although Jordan has no nuclear power industry, responses were consistent with previous research (Dunlap, Kraft \& Rosa, 1993; Whitfield, Rosa, Dan, \& Dietz, 2009) in reflecting a belief that nuclear power poses a public risk, indicating a continuing ambivalence towards the technology. In 2009, the Jordan Atomic Energy Commission, in cooperation with a consortium headed by the Korean Atomic Energy Research Institute, signed an agreement to build its first $5 \mathrm{MW}$ research reactor by 2014. Jordan then plans to build at least one reactor by 2019, to meet the high demand for electricity. Similar to the debate in the West in the 1960s, Jordan's government is facing increase opposition to using nuclear technology. It is relatively easy for opposition to increase following negative events, such as the recent Fukushima accident, but very difficult, according to Rosa and Dunlap (1994), to increase nuclear support, even after long periods of safe operation. Hence, whether a new generation in a country with no nuclear power or one with safe reactors can redirect public attitudes to be supportive of the technology is highly problematic. According to Hung and Wang (2011) and Visschers and Siegrist (2013), people's perception of the risks of nuclear technology is influenced by trust, which the risk perception literature (e.g. Whitfield et al., 2009) has often described as fragile; once broken, trust is hard to regain.

Results concerning global warming or 'climate change', unlike U.S. students but like Japanese students (Kleinhesselink \& Rosa, 1991) and Chileans (Bronfman \& Cifuentes, 2003), Jordanians located climate change in the lower right quadrant, in the space between factors 1 and 2.

\subsubsection{Not Dreaded but Unknown Risks and Known but Not Dreaded Risks}

The risks to Jordanian society of vaccination, smoking, unemployment, food preservatives, drug side effects, car accidents, inflation, gene technology, national conflicts, extreme poverty, pesticides and robbery were perceived as not dreaded but unknown, whereas those of alcohol and handguns were perceived as known and not dreaded.

\section{Conclusions, Implications and Limitations}

This study was motivated by a need to address a lack of understanding of risk perception in developing countries. It is one of the first to develop a cognitive map and to investigate factors influencing risk perception in Jordan, a country in the volatile Middle East region. To avoid criticisms associated with using students as its core sample, the study used a representative sample of Jordan's 12 provinces.

The results confirm the view of Sjöberg $(1996 ; 1997)$ that the psychometric model has explanatory power. The cognitive map provides some insight into how Jordanians perceive the risks associated with 25 technologies and activities. Except for age, no significant disparities were found for any of the risk dimensions across the nine risk characteristics. However, participants older than 51 years perceived the risk of road accidents as higher than other age groups did. The results also confirm the conclusion of Bronfman and Cifuentes (2003) that the psychometric paradigm can be applied to characterise perceived risk in a developing country, with relative success. Consequently, similar factors, with few differences in their composition, were identified. The first factor, dread of risk, was highly correlated with newness, common/dreaded and chronic, while knowledge of risk was positively correlated with knowledge of exposure and severity, and negatively correlated with voluntariness of risk.

Refugee influx, warfare and nuclear power were perceived as dreaded but known hazards with the highest societal and personal risk perceptions. These characteristics explain the increasing opposition of Jordanians to the proposed nuclear power project. Such risks will continue to be targets for future public discussion and interest. Similarly, terrorist attack was perceived as one of the most dreaded but known hazards, with very high 
societal risk but low personal risk perceptions. One explanation for this result is that terrorism has a negative impact upon the country's economy and is ultimately a nationality-specific risk. In contrast to the above risks, alcohol and handguns were perceived as known and not dreaded hazards. Gene technology, interestingly, was perceived as an unknown but not dreaded activity. The benefits derived from it may have an impact upon society's attitude toward it, in accordance with reports in the literature that the acceptability of a risk correlates positively with perceived social benefit. The perceived risk of dreaded hazards can thus be reduced by identifying and emphasising their benefits.

Although this study does fill some of the major theoretical gaps in the existing literature, a proper interpretation of the results requires an appreciation of the plasticity of risks; any given risk can vary and change in any direction. Changes in scientific knowledge about risks, media coverage and globalisation of risk issues are likely to have an influence on how people perceive risk. The relatively high educational level of the study sample may well also have influenced the ratings. An exploratory analysis showed that educational level influences risk ratings. More research is therefore needed to examine these changes and determine other possible variables that influence risk ratings.

It is difficult to make meaningful comparisons between the findings of this study and those of previous ones; the present study, for example, used a representative sample rather than only college students as in many previous studies (e.g. Slovic et al., 1980; Kleinhesselink \& Rosa, 1991; Keown, 1989; Englander et al., 1986; Teigen et al., 1988). Since the use of students as a core sample has been criticised, future research might include different groups of participants with a technological, ecological or feminist background and experts in various fields, such as psychology, technology and geography. Although stratified sampling was adopted to improve the representativeness of the sample, convenience sampling rather than systematic sampling was applied within each stratum. This is a non-probability method and it might be more appropriate for future research to use probability sampling.

\section{References}

Al Khattab, A., Anchor, J., \& Davies, E. (2007). Managerial perception of political risks in international projects. $\begin{array}{llll}\text { International Journal of Project } & \text { Management, }\end{array}$ http://dx.doi.org/10.1016/j.ijproman.2007.03.006

Boholm, ̊̊. (1998). Comparative studies of risk perception: a review of twenty years of research. Journal of Risk Research, 1(2), 135-163. http://dx.doi.org/10.1080/136698798377231

Bronfman, N., \& Cifuentes, L. (2003). Risk perception in a developing country: The case of Chile. Risk Analysis, 23(6), 1271-1285. http://dx.doi.org/10.1111/j.0272-4332.2003.00400.x

Brynen, R. (2006). Perspectives on Palestinian repatriation. In Taylor \& Francis (Eds.), Palestinian Refugee Repatriation: Global Perspectives (pp. 63-86, p. 80).

Burns, R. (2000). Introduction to Research Methods. London: SAGE Publications.

Cha, J. (1997). Environmental risk analysis: Factors influencing nuclear risk perception and policy implications (Unpublished doctoral dissertation). The University of New York, Albany, New York.

Chatelard, G. (2010). Jordan: A Refugee Haven. Institut Français du Proche-Orient (IFPO). Retrieved from http://www.migrationpolicy.org/article/jordan-refugee-haven

Creswell, J. W. (1998). Qualitative inquiry and research design: Choosing among five designs. Thousand Oaks, CA: Sage.

Davidson, D., \& Freudenburg, W. (1996). Gender and Environmental Risk Concerns: A Review and Analysis of Available Research. Environment and Behavior, 28, 302-339. http://dx.doi.org/10.1177/0013916596283003

Dillman, D. (1991). The design and administration of mail surveys. Annual Review of Sociology, 17, 225-249. http://dx.doi.org/10.1146/annurev.so.17.080191.001301

Dohle, S., Keller, C., \& Siegrist, M. (2010). Examining the Relationship Between Affect and Implicit Associations: Implications for Risk Perception. Risk Analysis, 30, 1116-1128. http://dx.doi.org/10.1111/j.1539-6924.2010.01404.x

Dosman, D., Wiktor, A., \& Steve, E. (2001). Socioeconomic determinants of health- and food safety-related risk perceptions. Risk Analysis, 21(2), 307-317. http://dx.doi.org/10.1111/0272-4332.212113

Dunlap, R., Kraft, M., \& Rosa, E. (1993). The Public and Nuclear Waste: Citizen's Views of Repository Sitting. Durham, NC: Duke University Press. 
Eiser, R., Podpadec, J., Reicher, D., \& Stevenage, V. (1998). Muddy waters and heavy metal: Time and attitude guide judgments of pollution. Journal of Environmental Psychology, 18, 199-208. http://dx.doi.org/10.1006/jevp.1998.0085

Englander, T., Farago, K., Slovic, P., \& Fischhoff, B. (1986). A comparative analysis of risk perception in Hungary and United states. Journal of Social Behaviour, 1, 55-60.

Field, A. (2013). Discovering Statistics using IBM SPSS Statistics (4th ed.). London: SAGE Publications.

Finer, J., \& Mehdawi, N. (2005, November 10). Bombings Kill Over 50 At 3 Hotels In Jordan. Washington post Foreign Service.

Fischhoff, B., Slovic, P., Lichtenstein, S., Read, S., \& Combs, B. (1978). How safe is safe enough? A psychometric study of attitudes towards technological risks and benefits. Policy Sciences, 9, 127-152. http://dx.doi.org/10.1007/BF00143739

Frank, E., Eakin, H., \& López-Carra, D. (2010). Risk Perception and Adaptation to Climate Risk in the Coffee Sector of Chiapas, Mexico. Conference on International Research on Food Security, Natural Resource Management and Rural Development, Tropentag, ETH Zurich.

Freedom House: Freedom in the World 2013. (2013, January). Retrieved from http://www.ecoi.net/local_link/245318/355272_en.html (accessed 24 April 2013)

Gabriel, I., \& Nyshadham, E. (2008). A cognitive map of people's online risk perceptions and attitudes: An empirical study. Proceedings of the 41st Hawaii International Conference on System Sciences. Hawaii.

Goszczynska, M., Tyszka, T., \& Slovic, P. (1991). Risk perception in Poland: A comparison with three other countries. Journal of Behavioral Decision Making, 4, 179-193. http://dx.doi.org/10.1002/bdm.3960040305

Healey, B., \& Rawlinson, J. (1994). Interviews Techniques in Business and Management Research. Aldershot: Dartmouth.

Hinman, G., Rosa, E., Kleinhesselink, R., \& Lowinger, T. (1993). Perception of Nuclear and Other Risks in Japan and the United States. Risk Analysis, 13, 449-456. http://dx.doi.org/10.1111/j.1539-6924.1993.tb00745.x

Hung, C., \& Wang, W. (2011). Determinants and mapping of collective perceptions of technological risk: The case of the second nuclear power plant in Taiwan. Risk Analysis, 31(4), 668-683. http://dx.doi.org/10.1111/j.1539-6924.2010.01539.x

Karpowicz-Lazreg, C., \& Mullet, E. (1993). Societal risk as seen by the French public. Risk Analysis, 13, 253-258. http://dx.doi.org/10.1111/j.1539-6924.1993.tb01076.x

Kellens, W., Zaalberg, R., Neutens, T., Vanneuville, W., \& De Maeyer, P. (2011). An Analysis of the Public Perception of Flood Risk on the Belgian Coast. Risk Analysis, 31, 1055-1068. http://dx.doi.org/10.1111/j.1539-6924.2010.01571.x

Keown, C. (1989). Risk perceptions of Hong Kongese vs. Americans. Risk Analysis, 9(3), 401-405. http://dx.doi.org/10.1111/j.1539-6924.1989.tb01005.x

Kleinhesselink, R. R., \& Rosa, E. A. (1991). Cognitive representations of risk perceptions: a comparison of Japan and the United States. Journal of Cross-Cultural Psychology, 22, 11-28. http://dx.doi.org/10.1177/0022022191221004

Knuth, D., Kehl, G., Hulse, L., Sans, J., Valles, L., \& Roiha, M. ( 2013). BeSeCu-S- A Self-report Instrument for Emergency Survivors. Journal of Risk Research. http://dx.doi.org/10.1080/13669877.2013.815649

Lai, J., \& Tao, J. (2003). Perception of environmental hazards in Hong Kong Chinese. Risk Analysis, 23(4), 669-684. http://dx.doi.org/10.1111/1539-6924.00346

Lemyre, L., Lee, J., Mercier, P., Bouchard, L., \& Krewsk, D. (2006). The structure of Canadians' health risk perceptions: Environmental, therapeutic and social health risks. Journal of Health, Risk \& Society, 8(2), 185-195. http://dx.doi.org/10.1080/13698570600677399

Loewenstein, G., Weber E., Hsee, C., \& Welch, N. (2001). Risk as Feeling. Psychological Bulletin, 127(2), 267-286. http://dx.doi.org/10.1037/0033-2909.127.2.267

Mun, S. (2004). The Perception of Risk in Sport Activities. Florida State University.

Oppenheim, N. (1992). Questionnaire design, interviewing and attitude measurement. London: Pinter 
Publishers.

Otway, H., \& Cohen, J. (1975). Revealed Preferences: Comments on the Starr benefit-Risk Relationships. Research Memorandum, 75-5.

Renn, O., \& Tohrmann, B. (2000). Cross-Cultural Risk Perception: A survey of Empirical Studies. Boston: Kluwer Academic Publishers.

Robson, C. (1993). Real World Research: A Resource for Social Scientists and Practitioners-Researchers. Oxford: Blackwell.

Rohrmann, B. (1999). Risk Perception Research: Review and Documentation. Melbourne: University Press.

Rosa, E., \& Dunlap, R. (1994). The polls-poll trends: Nuclear energy: Three decades of public opinion. Public Opinion Quarterly, 58, 295-325. http://dx.doi.org/10.1086/269425

Rowe, G., \& Wright, G. (2001). Differences in expert and lay judgments of risk: myth or reality. Risk Analysis, 21(2), 341-356. http://dx.doi.org/10.1111/0272-4332.212116

Rust, J., \& Golombok, S. (1989). Modern Psychometrics: The Science of Psychological Assessment. London: Routledge.

Saunders, M., Lewis, P., \& Thornhill, A. (2000). Research methods for business students (2nd ed.). Harlow: Pearson Education.

Savadori, L., Rumiati, R., \& Bonini, N. (1998). Expertise and regional differences in risk perception: The case of Italy. Swiss Journal of Psychology, 57, 101-113.

Savage, I. (1993). Demographic influences on risk perceptions. Risk analysis, 13(4), 413-20. http://dx.doi.org/10.1111/j.1539-6924.1993.tb00741.x

Siegrist, M. (2000). The influence of trust and perceptions of risks and benefits on the acceptance of gene technology. Risk Analysis, 20, 195-203. http://dx.doi.org/10.1111/0272-4332.202020

Siegrist, M., Cousin, M. E., Kastenholz, H., \& Wiek, A. (2007). Public acceptance of nanotechnology foods and food packaging: The influence of affect and trust. Appetite, 49(2), 459-466. http://dx.doi.org/10.1016/j.appet.2007.03.002

Siegrist, M., Keller, C., \& Kiers, H. (2005). A New Look at the Psychometric Paradigm of Perception of Hazards. Risk Analysis, 25(1), 211-222. http://dx.doi.org/10.1111/j.0272-4332.2005.00580.x

Sjöberg, L., Moen, B., \& Rundmo, T. (2004). Explaining risk perception. An evaluation of the psychometric paradigm in risk perception research, Rotunde, Trondheim, 84.

Sjöberg, L. (1996). A discussion of the limitations of the psychometric and cultural theory approaches to risk perception. Radiat Prot Dosimetry, 68, 219-225.

Sjöberg, L. (1997). Explaining risk perception: an empirical evaluation of cultural theory. Risk Decision and Policy, 2(2), 113-130. http://dx.doi.org/10.1080/135753097348447

Sjöberg, L. (1999). Political Decisions and Public Risk Perception. The third international public policy and social science conference. Oxford, St Catherine's College.

Sjöberg, L. (2000). Factors in Risk Perception. Risk Analysis, 20. http://dx.doi.org/10.1111/0272-4332.00001

Sjöberg, L. (2002). Are Received Risk Perception Models Alive and Well? Risk Analysis, 22, $665-669$. http://dx.doi.org/10.1111/0272-4332.00058

Sjöberg, L. (2004). Local Acceptance of a High-Level Nuclear Waste Repository. Risk Analysis, 24, 737-749. http://dx.doi.10.1111/j.0272-4332.2004.00472.x

Sjöberg, L., \& Wahlberg, A. (2002). Risk perception and new age beliefs. Risk Analysis, 22, $751-764$. http://dx.doi.org/10.1111/0272-4332.00066

Sjöberg, L., Kolarova, D., Rucai, A., \& Bernstrom, M. (2000). Risk Perception in Bulgaria \& Romania. In O. Renn \& B. Rohrmann (Eds.), Cross Cultural Risk Perception. Dordrecht: Kluwer Academic Publishers.

Slovic P. (2000). The perception of risk. London: Earthscan.

Slovic, P. (1987). Perception of risk. Science, 236, 280-285. http://dx.doi.org/10.1126/science.3563507

Slovic, P. (1999). Trust, Emotion, Sex, Politics, and Science: surveying the risk- assessment battlefield. Risk Analysis, 19. http://dx.doi.org/10.1111/j.1539-6924.1999.tb00439.x 
Slovic, P., Finucane, M. L., Peters, E., \& MacGregor, D. G. (2004). Risk as analysis and risk as feelings: some thoughts about affect, reason, risk and rationality. Risk Analysis, 24(2), 311-322. http://dx.doi.org/10.1111/j.0272-4332.2004.00433.x

Slovic, P., Fischhoff, B., \& Lichtenstein, S. (1980). Facts and fears: understanding perceived risk. In R. Schwing \& W. Alberts Jr. (Eds.), Societal Risk Assessment: How Safe is Safe Enough? New York: Plenum Press.

Slovic, P., Fischhoff, B., \& Lichtenstein, S. (1981). Perceived risk: Psychological factors and social implications. Proceedings of the Royal Society of London. London 17-34. http://dx.doi.org/10.1098/rspa.1981.0073

Slovic, P., Flynn, J., Mertz, C., Poumadere, M., \& Mays, C. (1996). Nuclear Power and the Public: A Comparative Study of Risk Perception in France and the United States. In O. Renn \& B. Rohrmann (Eds.), Cross Cultural Risk Perception. Dordrecht: Kluwer Academic Publishers.

Slovic, P., MacGregor, D., \& Kraus, N. (1987). Perception of risk from automobile safety defects. Accident Analysis \& Prevention, 19, 359-373. http://dx.doi.org/10.1016/0001-4575(87)90022-4

Sowby, F. (1965). Radiation and Other Risks. Health Physics, 11, 879-887. http://dx.doi.org/10.1097/00004032-196509000-00008

Sparks, P., \& Shepherd, R. (1994). Public perceptions of the potential hazards associated with food production and food consumption: an empirical study. Risk Analysis, 14(5), 799-806. http://dx.doi.org/10.1111/j.1539-6924.1994.tb00291.x

Starr, C. (1969). Social Benefit versus Technological Risk. Science, 165, 1232-1238. http://dx.doi.org/10.1126/science.165.3899.1232

Sundblad, L., Biel, A., \& Gärling, T. (2007). Cognitive and affective risk judgments related to climate change. Journal of Environmental Psychology, 27, 97-106. http://dx.doi.org/10.1016/j.jenvp.2007.01.003

Teigen, H., Brun, W., \& Slovic, P. (1988). Societal risks as seen by the Norwegian public. Journal of Behavioural Decision Making, 1, 111-30. http://dx.doi.org/10.1002/bdm.3960010205

Thomson, M., Önkal-Atay, D., \& Güvenç, G. (2003). A Cognitive Portrayal of Risk Perception in Turkey: Some Cross-national Comparisons. Risk Management, 5, 25-35. http://dx.doi.org/10.1057/palgrave.rm.8240162

Visschers, M., \& Siegrist, M. (2013). How a Nuclear Power Plant Accident Influences Acceptance of Nuclear Power: Results of a Longitudinal Study Before and After the Fukushima Disaster. Risk Analysis, 33, 333-347. http://dx.doi.org/10.1111/j.1539-6924.2012.01861.x

Weinstein, D. (1987). Unrealistic optimism about susceptibility to health problems: conclusions from a community-wide sample. Journal of Behavioral Medicine, 10, 481-498. http://dx.doi.org/10.1007/BF00846146

Whitfield, C., Rosa, A., Dan, A., \& Dietz, T. (2009). The Future of Nuclear Power: Value Orientations and Risk Perception. Risk Analysis, 29, 425-437. http://dx.doi.org/10.1111/j.1539-6924.2008.01155.x

\section{Copyrights}

Copyright for this article is retained by the author(s), with first publication rights granted to the journal.

This is an open-access article distributed under the terms and conditions of the Creative Commons Attribution license (http://creativecommons.org/licenses/by/3.0/). 